NBER WORKING PAPER SERIES

\title{
TECHNOLOGICAL DIFFUSION, CONDITIONAL CONVERGENCE, AND ECONOMIC GROWTH
}

\author{
David E. Bloom \\ David Canning \\ Jaypee Sevilla
}

Working Paper 8713

http://www.nber.org/papers/w8713

\author{
NATIONAL BUREAU OF ECONOMIC RESEARCH \\ 1050 Massachusetts Avenue \\ Cambridge, MA 02138 \\ January 2002
}

The views expressed herein are those of the authors and not necessarily those of the National Bureau of Economic Research.

(C) 2002 by David E. Bloom, David Canning and Jaypee Sevilla. All rights reserved. Short sections of text, not to exceed two paragraphs, may be quoted without explicit permission provided that full credit, including (C) notice, is given to the source. 
Technological Diffusion, Conditional Convergence, and Economic Growth David E. Bloom, David Canning and Jaypee Sevilla

NBER Working Paper No. 8713

January 2002

JEL No. O3, O4

\begin{abstract}
Technological diffusion implies a form of "conditional convergence" as lagging countries catch up with technological leaders. We find strong evidence of technological diffusion but not full convergence; differences in total factor productivity (TFP) persist even in the long run due to differences in geography and institutions. TFP differentials explain a large part of cross-country income differences in our model; our estimates of the rate of return to capital, labor and schooling are completely consistent with micro-economic studies, implying the absence of externalities in aggregate production.
\end{abstract}

David E. Bloom

Harvard University

Department of Population

and International Health

Building I, Room 1110B

677 Huntington Avenue

Boston, MA 02115

and NBER

dbloom@hsph.harvard.edu
David Canning

School of Economics

and Management

Queen's University of Belfast

d.canning@qub.ac.uk
Jaypee Sevilla

School of Public Health Harvard University jsevilla@fas.harvard.edu 


\section{Introduction}

Economic growth can be decomposed into two components; increases in factor inputs and improvements in total factor productivity (TFP), the efficiency with which factors are used. Calibration of growth models, using the private rates of return to factors calculated from microeconomic studies, suggests that differences in factor inputs explain a relatively small proportion of the large differentials in income levels we actually observe across countries and that the major force behind these differentials are differences in TFP. (e.g. Klenow and Rodriguez-Clare (1997), Prescott (1998)).

When growth relationships are estimated using macroeconomic data (e.g. Mankiw, Romer, and Weil (1992)) a greater role is often found for factor inputs. As emphasized by Mankiw (1997), the potential advantage of estimation is its ability to pick up externalities to physical and human capital that appear at the aggregate level but do not affect private returns. The estimation of the macroeconomic relationships that underlie economic growth has, however, a number of problems. To be valid, the estimated relationships should correctly specify the functional form of the production function (how factor inputs affect output), elucidate the dynamics of TFP (how the level, and growth rate, of TFP varies across countries), and control for the potential bias caused by reverse causality from income levels to investment in factor inputs.

In this paper our focus is on how we model the dynamics of TFP. One way of modeling TFP is to take it to be the same in every country (e.g. Mankiw, Romer, and Weil (1992)). It has been forcefully argued, however, that there are cross-country differences in TFP levels (e.g. Prescott 1998). The fixed effects approach (e.g. Islam (1995), Caselli, Esquivel and Lefort, (1996)) allows for TFP differentials across countries but assumes that these differentials persist indefinitely. 
While we wish to allow for cross-country differences in the level of TFP, we feel that not all these differences need be persistent. To the extent that differences in TFP reflect differences in technology, we expect to see these technology gaps close over time as technology diffuses. We estimate a model of technology diffusion, but allow for the possibility of some differentials in TFP even in the long run, due, for example, to differences in geography and institutions across countries.

A fundamental difficulty in modeling, and testing, theories of TFP is that we have no independent measure of TFP; instead, TFP appears as a residual in the production function. Nevertheless, our model of TFP places testable restrictions on the parameters being estimated and we can evaluate it using these tests. In addition, our model encompasses both the fixed effects approach (without technological diffusion), and the view that there are no differences in TFP across countries in the long run; we can test if these restricted models fit the data.

While we focus on the evolution of TFP, in order to model the growth process we also need to specify the form of the aggregate production function. The relative constancy of factor shares in GDP suggests a Cobb-Douglas specification for capital and labor inputs, though we also try a more general function form suggested by Duffy and Papageorgiou (2000). Rates of return to schooling are fairly constant across the countries of the world; we construct a production function that is consistent with this stylized fact.

A recurrent problem in estimating the aggregate production function is reverse causality. It seems likely that higher income leads to higher investment in physical and human capital; this means that our estimates of factor productivity may be biased upwards. We identify the effect of inputs on output by assuming that while current inputs may depend on current output, current productivity, and predicted productivity growth, they are uncorrelated with future productivity 
shocks. This assumption identifies the productivity of each input; testing its validity (though the use of over-identifying restrictions) is an important part of evaluating our model.

We test this model using cross-country panel data on income growth over the period 1970-1990. Surprisingly, we find that our all our parameter estimates on factor returns are very close to those found in microeconomic studies; indeed, the differences between our parameter estimates and the averages found across micro-studies are statistically insignificant. This implies the absence of externalities in aggregate production and that differences in TFP are the major source of cross-country differences in income levels.

The relationship we derive from our production function and model of technological diffusion has similarities to those found in the "conditional convergence" literature (e.g. Mankiw, Romer and Weil (1992), Islam (1995), Barro and Sala-i-Martin (1995)). However, the rationale for conditional convergence in our approach is quite different. Traditionally, "conditional convergence" occurs when a country's capital stock and output are lower than their steady-state levels. Catch-up occurs due to a high rate of investment as the capital stock grows towards its postulated steady-state level (which depends on the savings rate). In our model we account for the effect of capital accumulation directly and identify the "catch-up" term in economic growth as technological progress. When a country's output is low given its factor inputs we have evidence of low TFP, and we expect to see economic growth as TFP converges towards its steady state level. Our results imply that TFP in each country is converging towards a steady state level at about $1.8 \%$ a year, though the steady state does vary across countries depending on their geography and institutions.

Section 2 describes our theoretical model and its properties. Section 3 describes the data. Estimation results are reported and discussed in Section 4. An important implication of our 
explicit modeling of the process of technological diffusion is that it places some strong restrictions on the parameters in our regressions. In section 4 we also test these restrictions to ensure that the data is compatible with the model we use. Section 5 gives our conclusions.

\section{Theory}

We want to construct a production function where we model both how inputs and TFP affect output and how TFP evolves. We assume that the production function has the form

$$
Y=A F(K, L, s)
$$

where $\mathrm{Y}$ is total GDP, A represents TFP, $\mathrm{K}$ is the physical capital stock, $\mathrm{L}$ is the labor force, and $\mathrm{s}$ is the average years of schooling of the workforce. We begin by modeling the production function $\mathrm{F}$ and then turn to the issue of how TFP is determined.

The relative constancy of the shares of capital and labor in total income across the world suggests a Cobb-Douglas functional form for these inputs. For human capital the story is more difficult since we need to separate out the reward to human capital from the reward to raw labor in the wage bill. Unfortunately, wage payments do not distinguish between these two rewards, but there have been many microeconomic studies of the effect of human capital on wages, based on the work of Mincer (1974). This relationship is usually taken to have the form:

$$
\log w_{j}=\alpha_{0}+\alpha_{1} s_{j}
$$

where $w_{j}$ is the wage of individual $j$, and $s_{j}$ is his years of schooling. Note that the semi-log form of the relationship implies that schooling exerts a multiplicative rather than additive effect on wages. The marginal product of an extra year of schooling is $\alpha_{1} w_{j}$. The coefficient $\alpha_{1}$ is therefore rate of return to schooling (assuming that the only cost of schooling are foregone 
earnings of $\mathrm{j}$ while studying). In this framework the rate of return to education is the same for each worker.

Bils and Klenow (2000) report estimates of this equation for 52 countries based on the work of Psacharopoulos (1994). Taking crude averages of the parameter estimates, we find a coefficient of 0.091 on schooling. This implies that each year of education raises subsequent wages by about $9 \%$. The returns to education reported in Bils and Klenow (2000) are fairly constant across countries and do not vary systematically with national income level or average years of schooling of the workforce. This makes using a Cobb-Douglas production function including education problematic; with a Cobb-Douglas function the rate of return to education (the marginal product of education divided by its cost, which is the output lost by withdrawing a worker from the labor force, that is, the marginal product of labor) is inversely proportional to the average years of schooling of the workforce. This would imply very high returns to education in poor countries where education stocks are low (in excess of ten times the rates of return found in the U.S); these high rates are not found in micro-studies. ${ }^{1}$

Instead we consider the aggregate production function

$$
Y=A K^{\alpha} L^{\beta} e^{\phi s}
$$

Using this functional form, and assuming each factor earns its marginal product, $\alpha$ is the share of national income that goes to capital while $\beta$ is the share of national income going to wages, which includes both the rewards to labor and to schooling. The marginal product of a worker with average human capital is $\beta Y / L$. On the other hand, the marginal product of an extra year of education is $\phi^{Y} / L$. It follows that, if we assume that the only cost of education is the lost output of the worker being educated, an extra year of education for an average worker has a 
social rate of return ${ }^{2}$ of $\phi / \beta$. The intuition for this ratio is that the extra year of schooling adds proportionately to output, but its cost is the wage forgone, which depends on labor's share of output. Using this we can compare the results of estimating a production function like (2) with the rates of return found in (1).

However, this analysis only gives the rate of social return for an average worker. We can calculate the social rate of return for a worker with $s_{j}$ years of education as

$$
\frac{\phi}{\beta+\phi\left(s_{j}-s\right)}
$$

which implies that different workers face different rates of return to education. This problem must occur in any model in which aggregate output depends only on average (or total) years of schooling since, in this case, the marginal benefit of a extra year of schooling is the same no matter who has it, while the cost in term of output forgone by withdrawing a working from the labor force is lower for workers with low levels of education than for those with high levels of education. If we want to have an aggregate production function that preserves the Mincer equation property that the rate of return to education is constant across workers, it needs to include the distribution, as well as the average level, of human capital.

In the interests of simplicity we assume only the total stock of education matters, not its distribution. We can, however, calculate the rate of return to a policy of increasing everyone's education level by the same amount and compare this with the microeconomic estimates from (1). Increasing everyone's education by the same amount has the marginal product $\phi Y$, while the wages forgone are $\sum_{j}\left(\beta+\phi\left(s_{j}-s\right)\right) Y=\beta Y$, so the rate of return to a policy of universal schooling is again $\phi / \beta$. 
Heckman and Klenow (1997) and Krueger and Lindahl (2000) take a different approach to calculating the rate of return to schooling. They add over workers to produce an "aggregate Mincer equation" that appears to imply that the rate of return to schooling in equation (3) is simply $\phi$. However, the "aggregate Mincer equation" approach is not appropriate in our framework. It implicitly assumes the wage of a worker with no education to be independent of the average level of education in the workforce, but it is easy to show that the production function given by equation (3) implies that the wage (i.e. the marginal product) of an uneducated worker does depend on the average level of education. This issue is addressed in detail in the Appendix.

Taking logs of the aggregate production function (3), we can derive an equation for the $\log$ of aggregate output in country $i$ at time $t$

$$
y_{i t}=a_{i t}+\alpha k_{i t}+\beta l_{i t}+\phi s_{i t}
$$

where $\mathrm{y}_{\mathrm{it}}, \mathrm{k}_{\mathrm{it}}$, and $\mathrm{l}_{\mathrm{it}}$ are the $\operatorname{logs}$ of $\mathrm{Y}_{\mathrm{it}}, \mathrm{K}_{\mathrm{it}}$, and $\mathrm{L}_{\mathrm{it}}$ respectively, while the schooling variable, $\mathrm{s}_{\mathrm{it}}$, is in levels. Equation (5) is an identity, but in practice $a_{i t}$, the level of total factor productivity in country $i$ at time $t$, is not observed and appears as an error term in the equation when we come to estimation.

We now address the crucial issue of how to model this error term. We assume TFP follows the process:

$$
a_{i t}=a_{i t}^{*}+v_{i t} \text { where } v_{i t}=\rho v_{i, t-1}+\sigma_{t}+\varepsilon_{i t}
$$

where $\sigma_{t}$ is a common worldwide shock (due, for example, to macroeconomic conditions) at time $\mathrm{t}$, and $\varepsilon_{i t}$ is a country specific random shock. Each country has a long run steady state level of TFP given by $a_{i t}^{*}$. One simple approach is to imagine that $a_{i t}^{*}$ is the same for every country, 
but changes over time, so that $a_{i t}^{*}=a_{t}$. In this case, $v_{\text {it }}$ represents a country specific “technology gap" from the common world technological level at time t. This deviation from steady state TFP levels may be persistent, but as time passes, TFP levels converge the world TFP level at the rate $1-\rho$. The rate at which TFP converges measures the speed of technological diffusion.

While technology may eventually diffuse, some countries may enjoy long run advantages in TFP that do not get eroded over time. For example, while technology may diffuse slowly as patent protection runs out, differences in institutional arrangements may persist unchanged throughout the time periods we consider. In addition, geographical factors may mean that some locations have productivity differentials, even in the long run. This suggests that we should model long run TFP as $a_{i t}^{*}=f\left(x_{i}\right)+a_{t}$, where the variables in $x_{i}$ are country specific factors that may affect long run TFP. For example, Hall and Jones (1999) argue that institutions and “social infrastructure” can affect productivity, while Gallup, Sachs and Mellinger (1999) emphasize the role of geography. In practice, we use the percentage area in the tropics and a measure of institutional quality as factors that determine long run TFP levels.

For estimation purposes it is useful to turn our production function into a growth equation. Differencing equation (5) gives us

$$
\Delta y_{i t}=\Delta a_{t}+\alpha \Delta k_{i t}+\beta \Delta l_{i t}+\phi \Delta s_{i t}+\Delta v_{i t}
$$

Substituting out the error term, and noting that the lagged productivity gap $v_{i, t-1}$ is the difference between actual and predicted output at time t-1 generates:

$$
\Delta y_{i t}=\Delta a_{t}+\sigma_{t}+\alpha \Delta k_{i t}+\beta \Delta l_{i t}+\phi \Delta s_{i t}
$$




$$
+(1-\rho)\left(f\left(x_{i}\right)+a_{t-1}+\alpha k_{i, t-1}+\beta l_{i, t-1}+\phi s_{i, t-1}-y_{i, t-1}\right)+\varepsilon_{i t}
$$

Growth in output can be decomposed into four components. The first is the growth of world total factor productivity plus any macroeconomic "shock" to world output. The second is the growth of inputs, capital, labor, and schooling. The third a catch-up term as some of the country's TFP gap, $v_{i, t-1}$, is closed and the country converges, at the rate $1-\rho$, to its steady state level of TFP. Finally there is an idiosyncratic shock to the country's TFP, $\varepsilon_{i t}$.

In the special case that $\rho=1$ the lagged level terms in equation (7) dissappear. Our approach therefore encompases the estimation of the production function in first differences as advocated by Pritchett (1996) and Krueger and Lindahl (2000), and we can test if this restriction holds. Taking first differences nets out any fixed effects in TFP. Therefore, testing $\rho=1$ tests the null of a fixed effects model, with persistent differentials in TFP, against the alternative that TFP differentials narrow over time due to technological diffusion ${ }^{3}$. Our model also encompasses the special case where there is technological diffusion but that the steady state level of TFP is the same in every country; we can test this by testing that the country specific variables $\mathrm{x}_{\mathrm{i}}$ have zero coefficients.

Equation (7) is essentially a model of conditional convergence. The speed of convergence, $1-\rho$, is the rate at which TFP gaps are converging. This is is sharp contrast with models (such as Mankiw, Romer, and Weil (1992) and Islam (1995)) that take TFP differentials across countries to be fixed; the speed of convergence in these models depends on the time period it takes for capital stocks to reach their steady state levels given fixed investment rates. By including the growth rates of factor inputs directly in equation (7) we can identify the catch- 
up term, the effect of the gap between actual output and steady state output given current input levels, as the impact of a TFP gap.

Estimating equation (7) has the potential difficulty that the contemporaneous growth rates of factor inputs are very likely to be endogenous and responsive to the current TFP shock, $\varepsilon_{i, t}$. We overcome this problem by instrumenting these current input growth rates with lagged input growth rates. We assume that these lagged input growth rates and the lagged levels of inputs are uncorrolated with $\varepsilon_{i, t}$, the current shock to TFP. This is quite compatible with lagged TFP levels and expected TFP growth (the catchup term in equation 7) affecting previous input decisions. The argument that the lagged input levels are uncorrolated with the current shock to TFP is the real rationale for estimating equation (7) rather than the level relationship in (5). If we were to estimate the level realtionship, there would be serious worry that the current input levels were correlated with the current level of TFP (which, after all, affects output and the pool of resources available for investment). In the levels equation, using lagged input levels as instruments is not appropriate because the autocorrelation in TFP over time means that lagged input levels can be correlated with lagged TFP levels which in turn are correlated with current TFP levels.

The lagged growth rates of inputs, and other variables we use, are valid instruments provided they are uncorrolated with future output shocks. We can test this using overidentifying restrictions. Another important set of restrictions imposed by our model is that the coefficients on each lagged input level and its current growth rate should be the same. Failure to satisfy these equality restricions would point towards a more complex error structure for TFP. 
In our model each time period has a constant term in its determination of cross country growth at time $t$, given by:

$$
d_{t}=\Delta a_{t}+\sigma_{t}+(1-\rho) a_{t-1}
$$

If we have $\mathrm{T}$ time periods in the model, we essentially have $\mathrm{T}$ time dummies, determined by $2 \mathrm{~T}+1$ parameters involving worldwide total factor productivity levels and output shocks. These parameters are therefore unidentified. We cannot distinguish between worldwide technical progress and a worldwide output shock. Even if we assume that there are no output shocks, we still cannot distinguish between worldwide average growth caused by technological innovation and growth caused by technological diffusion as countries catch up to a pre-existing world technology level. We could identify the model by making some arbitrary assumptions (e.g. that a particular country was at the technological frontier in the base year), but these arbitrary assumptions would completely detemine the level and growth rate of technology.

This lack of identification seems fundamental; it is impossible using only data on world average TFP improvements to decide if these are due to the incorporation of existing technology into production or the incorporation of new technology invented during the period. While these parameters are unidentified they affect only the constant term and do not hamper the estimation of the other parameters in the model.

\section{Data}

We construct a panel of countries observed every ten years from 1960 to 1990. Output data (GDP) is obtained from the Penn World Tables version 5.6 (see Summers and Heston (1991) for a description). We obtain total output by multiplying the real per capita GDP measured in 1985 international purchasing power parity dollars (chain index), by national population. 
Data on economically active population are from the International Labor Organization (1997). Our labor supply is given by their estimates of the total economically active population in the given year, though this does not adjust for the fact that some fraction of the labor force is unemployed and therefore should not be counted as providing labor inputs. Nor are we able to adjust for the hours worked of the labor force. Schooling is measured by the average total years of schooling of the population aged 15 plus from Barro-Lee (2000).

Our capital stock series for each country is computed by a perpetual inventory method. We initialize the capital series in the first year for which there is investment data in the Penn World Tables (version 5.6), setting it equal to the average investment/GDP ratio in the first five years of data, multiplied by the level of GDP in the initializing period, and divided by .07, our assumed depreciation rate. This is the capital stock we would expect in the initial year if the investment/GDP ratio we use is representative of previous rates. Each succeeding period's capital is given by current capital minus depreciation at 7\%, plus the level of current investment.

Our capital stock series has wider coverage than Summers-Heston variable for capital stock per worker, kapw, which is only available for 62 countries from 1965 onwards. Where the two overlap, the correlation coefficient between the log levels of our series and theirs is 0.97 , indicating that the two series are very similar. For many countries, investment series do not start until 1960, suggesting that our capital stock data for the 1960's may be suspect because of the way we construct the initial stock of capital. Because of depreciation, by 1970 the capital stock estimates become fairly independent of the initializing assumption used; we therefore limit our estimation to the period 1970-1990, though data from the period 1960-1970 are used as instruments. 
Our measure of institutional quality is the good governance variable from Knack and Keefer (1995), while percentage of land area in the tropics comes from Gallup, Sachs and Mellinger (1999).

\section{Estimation and Results}

We begin by estimating equation (7); the results are reported in column (1) of table 1 . Each regression is estimated by nonlinear least squares, and all contemporaneous growth rates of inputs are instrumented with their lagged growth rates and the lagged growth of output. Time dummies (not reported) are included.

In Column (1) of Table 1 we report results where we include physical capital, human capital and labor as inputs and assume that the steady state level of TFP is the same for every country. We find coefficients of close to 0.4 on capital and 0.6 labor, which seems a little high on capital compared to the evidence of its share of income. The sum of these coefficients on labor and capital is close to one and we cannot reject the restriction of constant returns to scale. Our estimate of the coefficient on schooling translates into a social rate of return of $23.1 \%$, which is somewhat higher than the average of $9.1 \%$ found in micro studies. However, our estimate is not very well determined and we cannot reject the hypothesis that it is the same as the microestimate of $9.1 \%$. The catch-up coefficient is 0.187 , indicating that TFP levels are converging at a rate of about $2 \%$ a year.

We include a number of specification tests in table 1. Equation (7) implies that the coefficients on the growth rates on inputs and their effect in the level part of the regression should be the same. These restrictions will fail in a model with a more complex error structure; for example, not all extra inputs added during the period may come "on stream" within the 
period, so that the effect of current input growth is less than the long run impact of the level of inputs. We can test this by estimating the unrestricted model, allowing the coefficients on the growth and level terms to differ for each input, and testing that the equality restrictions in equation (7) hold. In column (1), we find that we cannot reject the three equality restrictions (in fact the level and growth rate estimates of the coefficients are surprisingly close).

The inputs growth rates in equation (7) are endogenous and may be influenced by the growth rate of TFP during the period (the error term). This is likely in the ten year time periods we are using, since investments made later in the period will certainly be made in the light of TFP growth early in the period. Therefore, all our input growth terms are instrumented with lagged variables (the lagged input growth rates and lagged output growth) from before the current period. However, this identification strategy fails if lagged variables help predict the future productivity "shock" since in this case agents are able to predict the shock and base their input decisions on it. We use the Hausman specification test to test the hypothesis that the lagged variables are valid instruments; the test does not reject our instruments.

We now consider adding a geographic variable, the percentage of land area in the tropics, and an institutional quality variable to the model. Land area is fixed throughout the period and while institutional quality is measured in 1980 , we take it as representing a level that is also fixed over the whole period. If our model in column (1) is correct, and the error term represents an unpredictable "shock", we can add these variables as valid instruments. We try this approach in column (2) of table 1. The results in column (2) are similar to those found in column (1) with one notable exception. Our test for instrument validity generates a decisive rejection. This suggests that land area in the tropics and institutional quality are not valid instruments and can in fact help predict the residual from the regression. 
In column (3) we add land area in the tropics and institutional quality as explanatory variables in their own right by including them as determinants on long run steady state TFP. We find institutional quality to have a positive impact on long run TFP at the 5\% significance level, while the percentage of the country's land area that is in the tropics has a negative coefficient, though it is not quite significant at the $10 \%$ level. This suggests that long run steady state TFP varies across countries. We estimate that a country with the best possible institutions (score 10) has about $150 \%$ higher steady state TFP than a country with the worst (score zero), while a country wholly in the tropics has a TFP level about 50\% below that of a temperate country. Note that these estimated effects are only their effects on TFP. Poor geography and institutions may also lead to low returns to, and investment in, capital and education, so that their total impact on output may be much larger.

The capital and labor coefficients are close to $1 / 3$ and $2 / 3$ respectively which seems reasonable. The coefficients on capital and schooling fall when we add geographical factors; the estimates on these coefficients in columns (1) and (2) are likely to be biased upwards due to countries with favorable geography having higher TFP and income and higher induced levels of factor accumulation than expected. Our estimated coefficient on schooling in column (3) implies a rate of return of around $8.4 \%$ a year but the standard error on this estimate is large. The fact that schooling is not statistically significant in column (3) of table 1 might be taken as evidence that schooling does not affect growth, but this is not the appropriate inference. Formally, we cannot reject (at the 5\% significance level) the null hypothesis that schooling has no effect - but this is very different from accepting the null. In fact, we have a great deal of microeconomic evidence that the rate of return to schooling is around $9 \%$ per annum; this figure is a more interesting null hypothesis than that schooling does not affect output. We cannot reject this null 
hypothesis either, implying we cannot reject the hypothesis that there are no externalities to schooling over and above its private return. ${ }^{4}$

In all the specifications (1) - (3) the data appear to accept constant returns to scale. Imposing constant returns to scale allows us to divide the production function through by $\mathrm{L}$, the labor force, so that we can regard equation (4) as a regression explaining the growth on income per worker by the growth of capital and education per worker, and improvements in TFP. We can then rewrite equation (7) as

$$
\begin{gathered}
\Delta \log \left(Y_{i t} / L_{i t}\right)=\Delta a_{t}+\sigma_{t}+\alpha \Delta l\left(K_{i t} / L_{i t}\right)+\phi \Delta s_{i t} \\
+(1-\rho)\left(f\left(x_{i}\right)+a_{t-1}+\alpha \log \left(K_{i, t-1} / L_{i, t-1}\right)+\phi s_{i, t-1}-\log \left(Y_{i, t-1} / L_{i, t-1}\right)+\varepsilon_{i t}\right.
\end{gathered}
$$

Our estimates of this relationship are reported in column (4) of table 1. Imposing constant returns should improve efficiency of estimation, but in practice does not much affect the results.

Overall, the picture that emerges from table 1 is that the macro-results are surprisingly close to the results found in microeconomic studies. In every case we find that we cannot reject the hypothesis that the macroeconomic estimates on the returns to schooling are the same as the microeconomic evidence. The coefficient on capital of around $1 / 3$ is close to its factor share suggesting that its private reward reflects its aggregate productivity. There are large gaps in total factor productivity across countries but these gaps are being closed at the rate of about $2 \%$ a year. As we would expect, countries with better governance tend to have higher steady state levels of TFP while those in the tropics have lower TFP.

The specification tests in column (3) and (4) of table 1 are satisfactory. However, the actual relationship may be more complex. We experimented with a number of generalizations of our model. Following Duffy and Papageorgiou (2000) we can approximate a constant elasticity 
of substitution production function by including the square of log capital per worker term in the production function given by equation (5). A second idea is to allow the diffusion of technology to depend on the education level, as suggested by Nelson and Phelps (1966). This implies that countries with higher education may have less persistence in their technology gap; we also allow high education counties to have better access to new innovations. However, adding these effects did not improve the fit of the model significantly. ${ }^{5}$

Finally, there is clearly an issue as to what variables to include as determinants on long run TFP. We experimented with a number of candidates, including the Sachs and Warner (1995) openness measure and the ethic fractionalization measure used by Easterly and Levine (1997). However, we found none that added significantly to the fit of our regression once we include the percentage of the country's area that lies in the tropics and the quality of its institutions.

\section{Conclusion}

Our model accounts for economic growth by the growth of factor inputs, technological innovation and technological diffusion. We find no evidence that the macro-economic effects of capital accumulation and schooling are any greater to those found in micro studies. This suggests the absence of externalities at the aggregate level and that calibration studies based on microeconomic evidence on private returns provide reasonable pictures of the proximate sources of economic growth. As usual, we find evidence of conditional convergence in the growth data, but our framework allows us to interpret this specifically as evidence of technological diffusion.

The fact that we find no externalities puts the emphasis in explaining cross-country differences in income levels on how and why TFP varies across countries. As Prescott (1998) argues we need to say more than differences in TFP are important; we need a theory of TFP. Our 
results suggest that steady state TFP varies systematically across country with their geography and institutions but that convergence to this steady state level, through technological diffusion, is quite slow.

\section{Appendix}

Heckman and Klenow (1997) and Krueger and Lindahl (2000) derive their result by arguing that we can average equation (1) over workers. This gives a figure for the average of log wages. If, however, we assume that the distribution of wages is lognormal, the log of average wages is equal to the log of the median wage plus half the variance of wages (Hastings and Peacock (1975)). But, for a lognormal distribution, the log of the median wages equals the average of log wages (since log wages have a symmetrical distribution). Hence

$$
\log \bar{w}=\overline{\log w}+\frac{1}{2} \sigma^{2}=\alpha_{0}+\frac{1}{2} \sigma^{2}+\alpha_{1} \bar{s}
$$

where $\sigma$ is the standard deviation of $\log$ wages. Now if we assume that workers are paid their marginal products, we can calculate the marginal product of workers with each level of human capital from our aggregate production function and then add over workers to give

$$
\begin{gathered}
\log \bar{w}=\log \beta \frac{Y}{L} \\
=\log \beta+\log A+\alpha \log (K / L)+(\alpha+\beta-1) \log L+\phi \bar{s}
\end{gathered}
$$

This appears to be consistent with the aggregated Mincer equation (equation (A1) above) where the intercept of the wage equation varies across countries due to differences in total factor productivity A, capital per worker $\mathrm{K} / \mathrm{L}$, and a scale effect that depends on the size of the labor force (note that this dependence on L disappears if we have constant returns to scale, so that $\alpha+\beta=1$ ). It is now tempting to compare (A1) and (A2) and argue that the parameters on 
education in the micro and macro equations can be compared directly so that $\phi$, the coefficient on schooling, must be the return to education. However, this is not so.

The flaw in the argument is that when we aggregate the Mincer equation in (A1) we implicitly assumed that $\alpha_{0}$ was a constant, independent of the average level of education. But from equation (1) it is clear that $\alpha_{0}$ is the log wage of a worker with no education. While this can be regarded as fixed in a microeconomic study within a country, with our production function the wage of such a worker depends not only on TFP and capital per worker, but also on the average level of education. For example, assuming our production function (2) holds, and taking the simple case where $\mathrm{A}, \mathrm{K}$ and $\mathrm{L}$ are normalized to unity and setting the wage of a worker with education equal to his marginal product, we have

$$
\alpha_{0}=\log w_{0}=\log \left(\beta-\phi_{1} \bar{s}\right) \frac{Y}{L}=\log \left(\beta-\phi_{1} \bar{s}\right)+\phi \bar{s}
$$

This clearly implies that the wage earned by an uneducated worker depends on the average stock of education. ${ }^{6}$ Given our production function there is a fallacy of aggregation in (A1); the parameter $a_{0}$ is not a constant but should be written as a function of the average level of education. That is, the correct formulation of the "aggregate Mincer equation" is

$$
\log \bar{w}=\overline{\log w}+\frac{1}{2} \sigma^{2}=\alpha_{0}(\bar{s}, x)+\frac{1}{2} \sigma^{2}+\alpha \bar{s}
$$

which shows explicitly the dependence of the wage of an uneducated worker on the average level of education in the economy as well as other factors (such as the capital labor ratio), $\mathrm{x}$. The "aggregate Mincer equation" given by (A1) is only valid if $a_{0}$ does not depend on the average education level, which would require a production function somewhat different from ours. 


\section{References}

Barro, R. and Lee, J. 2000, "International Data on Educational Attainment: Updates and Implications," Center for International Development, Working Paper No. 42, Harvard University.

Barro, R. and Sala-I-Martin, X., 1995, Economic Growth, New York, McGraw-Hill.

Benhabib, J. and Spiegel, M., 1994, "The Role of Human of Capital in Economic Development: Evidence from Aggregate Cross-Country Data," Journal of Monetary Economics, Vol. 34, pp $143-74$.

Bils, M. and Klenow, P., 2000, "Does Schooling Cause Growth?" American Economic Review, Vol. 90, pp 1160-83.

Caselli F., Esquivel G. and Lefort F., 1996, "Reopening the Convergence Debate: A New Look at Cross Country Growth Empirics," Journal of Economic Growth, Vol. 1, pp 363-389.

Duffy J. and Papageorgiou C., 2000, "A Cross-Country Empirical Investigation of the Aggregate Production Function Specification," Journal of Economic Growth, Vol. 5, pp 87-120.

Easterly W. and Levine R., 1997, “Africa’s Growth Tragedy: Policies and Ethnic Divisions,” quarterly Journal of Economics, Vol. 112, pp 1251-1288. 
Gallup J.L., Sachs J.D., and Mellinger A., 1999, "Geography and Economic Development," International Regional Science Review, Vol. 22, pp 179-232.

Hall, R., and Jones, C., 1996, "The Productivity of Nations," NBER Working Paper No. 5812.

Heckman, J. and Klenow, P., 1997, Human Capital Policy, mimeo, Federal Reserve Bank of Minneapolis.

International Labor Organization, 1997, Economically Active Population, 1950-2010, Geneva, International Labor Organization.

Islam N., 1995, "Growth Empirics: A Panel Data Approach," Quarterly Journal of Economics, Vol. 110, pp 1127-70.

Klenow P.J. and Rodriguez-Clare A., 1997, "The Neoclassical Revival in Growth Economics:

Has it Gone Too Far?" in Bernanke, B. and Rotemberg, J. eds., NBER Macroeconomics Annual, pp 73-103 Cambridge, MA, MIT Press.

Knack S. and Keefer P., 1995, "Institutions and Economic Performance: Cross-Country Tests Using Alternative Institutional Measures," Economics and Politics, Vol. 7, pp. 207-227.

Krueger, A. and Lindahl, M., 2000, "Education for Growth: Why and for Whom?" NBER Working Paper, No. 7591. 
Mankiw N.G., 1997, "Comment on The Neoclassical Revival in Growth Economics: Has it Gone too Far," In Bernanke, B. and Rotemberg, J. eds., NBER Macroeconomics Annual, pp 103-107, Cambridge, MA, MIT Press.

Mankiw, N.G., Romer, D., and Weil, D., 1992, "A Contribution to the Empirics of Economic Growth," Quarterly Journal of Economics, Vol. 107, pp 407-37.

Mincer, J., 1974, Schooling, Earnings, and Experience, New York, Columbia University Press.

Nelson, R. and Phelps, E., 1966, "Investment in Humans, Technological Diffusion, and Economic Growth," American Economic Review, Vol. 56, pp. 69-75.

Prescott, E. C., 1998, "Needed: A Theory of Total Factor Productivity," International Economic Review, Vol. 39, pp. 525-51.

Pritchett, L., 1996, "Where Has All the Education Gone?" World Bank Policy Research Paper, No. 1581 .

Psacharopoulos G., 1994, "Returns to Investment in Education: A Global Update," World Development, Vol. 22, pp. 1325-1343. 
Sachs J.D. and Warner A., 1995, "Economic Reform and the Process of Global Integration," Brookings Papers on Economic Activity, Vol.1, pp 1-118.

Summers, R., and Heston, A., 1994, Penn World Tables v5.6, Revision of Summers R. and Heston, A., 1991, "The Penn World Table (Mark 5): An Expanded Set of International Comparisons, 1950-1988," Quarterly Journal of Economics, Vol. 106, pp 327-68.

United Nations, 1998, Demographic Indicators 1950-2050, New York: United Nations.

Young, A., 1994, "Lessons from the East Asian NIC's: A Contrarian View," European Economic Review, Vol. 38, pp. 964-973.

Young, A., 1995, "The Tyranny of Numbers: Confronting the Statistical Realities of the East Asian Growth Experience," Quarterly Journal of Economics, Vol. 110, pp. 641-680. 
Table 1

\begin{tabular}{|c|c|c|c|c|}
\hline & \multicolumn{4}{|c|}{$\begin{array}{l}\text { Production Function in Growth Form } \\
\text { Dependent Variable: Growth rate of GDP } \\
\text { Nonlinear two stage least squares }\end{array}$} \\
\hline & 1 & 2 & 3 & 4 \\
\hline Capital Coefficient & $\begin{array}{l}0.415^{* *} \\
(0.120)\end{array}$ & $\begin{array}{l}0.508^{* *} \\
(0.084)\end{array}$ & $\begin{array}{l}0.329 * * \\
(0.103)\end{array}$ & $\begin{array}{l}0.337^{* *} \\
(0.101)\end{array}$ \\
\hline Labor Coefficient & $\begin{array}{l}0.634 * * \\
(0.141)\end{array}$ & $\begin{array}{l}0.528 * * \\
(0.102)\end{array}$ & $\begin{array}{c}0.699 * * \\
(0.125)\end{array}$ & \\
\hline Schooling Coefficient & $\begin{array}{l}0.147^{*} \\
(0.073)\end{array}$ & $\begin{array}{l}0.100^{*} \\
(0.050)\end{array}$ & $\begin{array}{c}0.058 \\
(0.060)\end{array}$ & $\begin{array}{c}0.055 \\
(0.058)\end{array}$ \\
\hline $\begin{array}{l}\text { Technological Catch- } \\
\text { up Coefficient }\end{array}$ & $\begin{array}{l}0.187 * * \\
(0.041)\end{array}$ & $\begin{array}{l}0.199 * * \\
(0.040)\end{array}$ & $\begin{array}{l}0.167 * * \\
(0.040)\end{array}$ & $\begin{array}{l}0.171 * * \\
(0.041)\end{array}$ \\
\hline $\begin{array}{l}\text { Coefficient on Percent } \\
\text { Land Area in the } \\
\text { Tropics }\end{array}$ & & & $\begin{array}{l}-0.498 \\
(0.271)\end{array}$ & $\begin{array}{l}-0.500 \\
(0.260)\end{array}$ \\
\hline $\begin{array}{l}\text { Coefficient on Quality } \\
\text { of Institutions }\end{array}$ & & & $\begin{array}{l}0.150^{*} \\
(0.064)\end{array}$ & $\begin{array}{l}0.145^{*} \\
(0.061)\end{array}$ \\
\hline $\begin{array}{l}\text { Instruments for input } \\
\text { growth rates }\end{array}$ & $\begin{array}{l}\text { Lagged growth in } \\
\text { inputs and output }\end{array}$ & $\begin{array}{l}\text { Lagged growth in } \\
\text { inputs and output, } \\
\% \text { tropics and } \\
\text { institution quality }\end{array}$ & $\begin{array}{l}\text { Lagged growth in } \\
\text { inputs and output }\end{array}$ & $\begin{array}{l}\text { Lagged growth in } \\
\text { inputs and output }\end{array}$ \\
\hline $\begin{array}{l}\text { Estimate of the rate of } \\
\text { return to schooling }\end{array}$ & $\begin{array}{l}0.231 * * \\
(0.075)\end{array}$ & $\begin{array}{l}0.190^{* *} \\
(0.069)\end{array}$ & $\begin{array}{c}0.084 \\
(0.078)\end{array}$ & $\begin{array}{c}0.083 \\
(0.081)\end{array}$ \\
\hline $\begin{array}{l}\text { Test that rate of return } \\
\text { to schooling equals } \\
0.091\end{array}$ & $\begin{array}{c}3.52 \\
(1)\end{array}$ & $\begin{array}{l}2.04 \\
(1)\end{array}$ & $\begin{array}{c}0.01 \\
(1)\end{array}$ & $\begin{array}{c}0.01 \\
(1)\end{array}$ \\
\hline $\begin{array}{l}\text { Test of equality of } \\
\text { growth and level } \\
\text { coefficients }\end{array}$ & $\begin{array}{l}4.44 \\
(3)\end{array}$ & $\begin{array}{l}6.82 \\
(3)\end{array}$ & $\begin{array}{l}1.38 \\
(3)\end{array}$ & $\begin{array}{l}0.76 \\
(2)\end{array}$ \\
\hline $\begin{array}{l}\text { Overidentifying } \\
\text { restriction test on the } \\
\text { instruments }\end{array}$ & $\begin{array}{l}7.71 \\
(4)\end{array}$ & $\begin{array}{l}21.47 * * \\
(6)\end{array}$ & $\begin{array}{l}3.91 \\
(4)\end{array}$ & $\begin{array}{l}4.21 \\
(5)\end{array}$ \\
\hline $\begin{array}{l}\text { Test of constant } \\
\text { returns to scale }\end{array}$ & $\begin{array}{c}0.69 \\
(1)\end{array}$ & $\begin{array}{c}0.53 \\
(1)\end{array}$ & $\begin{array}{c}0.22 \\
(1)\end{array}$ & $\begin{array}{l}\text { Constant returns } \\
\text { to scale imposed }\end{array}$ \\
\hline
\end{tabular}

Estimated on 153 observations for the growth periods 1970-1980 and 1980-1990.

Year dummies are included throughout.

Estimates have standard errors in parenthesis, ${ }^{*}(*)$ denotes statistical significance at the $5 \%$ level $(1 \%)$ level. Tests are chi-squared under the null, with degrees of freedom in parenthesis. 
David E. Bloom

School of Public Health

Harvard Univ.

dbloom@hsph.harvard.edu

617-432-0654
David Canning

Dept. of Economics

Queen's Univ. of Belfast

d.canning@qub.ac.uk

44-2890-273281
Jaypee Sevilla

School of Public Health

Harvard Univ.

jsevilla@fas.harvard.edu

617-432-4054

${ }^{1}$ Using a Cobb-Douglas functional form also implies the growth rate of output depends on the growth rate of schooling so that we should see exceptionally large growth effects in countries, e.g. such as those in Africa, that have very low education levels but increase their education stocks a little (giving a high growth rate of schooling). The absence of such large growth effects in the data may lead to the conclusion that education does not matter, when it is really the functional form being employed that is to blame.

${ }^{2}$ The social rate of return is sometimes used to denote the return to schooling in terms of wage premium relative to the cost of both student time and teaching inputs. Here we use it to mean the increase in aggregate output relative to the cost of student time, which is directly comparable to the estimates of the private return in the literature that measure wage premium relative only to cost of student time.

${ }^{3}$ Formally, if we start with an encompassing model with both fixed effects and technological diffusion the "catch-up" term in equation (7) should still contain fixed effects. However, under the null of fixed effects alone no catch up term of any type should appear and so $\rho=1$ is still a valid test of fixed effects against a more general model even when $a_{i}$ in equation (7) is not a fixed effect.

${ }^{4}$ The argument that schooling has no effect on growth would be quite strong if we could not reject a zero coefficient and the standard errors on the estimate were small enough to reject the $9 \%$ rate of return found in microeconomic studies. This would imply that the individual returns to schooling might be due to improvements in rent seeking ability that were not reflected in aggregate productivity.

${ }^{5}$ The squared capital per worker term is positive and statistically significant when we exclude the geographical and institutional quality variables, but this is likely due to reverse causality; countries with good geography having higher TFP and so higher income levels that in turn generate high levels of factor inputs.

${ }^{6}$ Note that this formula holds for low levels of average education. If average education levels are high enough the marginal product of an uneducated worker may be negative (his negative impact in lowering the average years of schooling outweighs the pure effect of his labor supply) and he should not be employed. 